Електронне наукове фахове видання "Ефективна економіка" включено до переліку наукових фахових видань України з питань економіки (Категорія «Б», Наказ Міністерства освіти і науки України від 11.07.2019 № 975) www. economy.nayka.com.ua | № 11, 2020|26.11.2020 p.

DOI: $\underline{10.32702 / 2307-2105-2020.11 .23}$

УДК 339.92

\author{
O. Datsii
}

Doctor of Economic Sciences, Professor, Head of the Department of Finance, Banking and Insurance, Interregional Academy of Personnel Management ORCID ID: 0000-0002-7436-3264

K. Andriushchenko

Doctor of Economic Sciences, Professor,

Professor of the Department of Business Economics and Entrepreneurship, Kyiv National Economic University named after Vadym Hetman

ORCID ID: 0000-0002-6274-5310

\title{
CROSS-BORDER COOPERATION IN THE TERRITORIES OF THE CARPATHIAN EUROREGION IN THE CONDITIONS OF DEVELOPMENT OF INTERNATIONAL ECONOMIC RELATIONS AND GLOBALIZATION
}

\author{
O. I. Дайій,
}

д. е. н., професор, завідувач кафедри фінансів, банківської та страхової справи, Міжрегіональна академія управління персоналом

К. А. Андрющенко,

д. е. н., професор, професор кафедри бізнес-економіки та підприємництва, ДВНЗ «Київський національний економічний університет імені Вадима Гетьмана»

\section{ТРАНСКОРДОННЕ СПІВРОБІТНИЦТВО НА ТЕРИТОРІЯХ КАРПАТСЬКОГО ЄВРОРЕГІОНУ В УМОВАХ РОЗВИТКУ МІЖНАРОДНИХ ЕКОНОМІЧНИХ ЗВ'ЯЗКІВ ТА ГЛОБАЛІЗАЦЇ̈}

In the context of globalisation interstate borders in relation to economic relations have acquired a new meaning, which required the creation of a new system of regulation based on the principles of liberalisation, elimination of trade barriers, ensuring free movement of capital. On the one hand, the process of economic globalisation highlights the problems and contradictions remaining at the national level between the regulatory functions of state administrative bodies and the needs of unimpeded development of the Carpathian Euroregion. In this respect, inter-state institutions, as well as the harmonised legal norms underpinning them, prevent attempts to disrupt the competitive environment at the regional level. On the other hand, multilateral organisations are the mechanisms within which representatives of national administrations of the participating countries can negotiate the mutual removal of obstacles at the level of inter-state relations. Determined that, Those "dimensions" of the economy dominated by the "symbolic mediation" of relations - the financial market and consumption driven by consumerism - are most susceptible to globalisation. Much less globalised are commodity production and the labour market. There are theoretical 
justifications of the necessity of movement of the world community on the way of standardization in the field of economy. They found their adherents in the idea of combination, interpenetration, enrichment of national ways of development of economy not simply adjusting them to the general tendencies through destruction and suppression, but the way of connection on principles of equality, collectivism, preservation of traditional orientation of development. A certain development of theoretical views on the processes of globalisation influence on economic processes of specific countries we find in the works of specialists of the Club of Rome, as well as representatives of many international governmental and non-governmental organisations. They analyse in detail the processes of globalisation themselves and the obstacles that stand in their way. At the same time, external limits - limits arising from the past, and internal limits - limits arising from the future, which give birth to a more dangerous alternative to globalization - the movement of antiglobalization. Thus, it is hardly appropriate to speak of globalisation only as a process of continued growth of mutual trade, investment, increasing interdependence of countries and transcountry territories. Such an understanding of globalisation would be too simplistic and superficial and would not reveal qualitatively new elements of the globalisation process taking into account the manifestations of the specific development of the Carpathian Euroregion.

В умовах глобалізачії міждержавні кордони стосовно економічних відносин набули нового значення, що вимагало створення нової системи регулювання, заснованої на принципах лібералізації, усунення торгових бар'єрів, забезпечення вільного руху капіталу. 3 одного боку, прочес економічної глобалізації висвітлює проблеми та суперечності, щуо залишаються на національному рівні між регуляторними функиіями державних адміністративних органів та потребами безперешкодного розвитку Карпатського єврорегіону. У иььому відношенні міждержавні інституції, а також гармонізовані правові норми, щуо лежать в їх основі, запобігають спробам порушити конкурентне середовище на регіональному рівні. 3 іншого боку, багатосторонні організації є механізмами, в рамках яких представники національних адміністрацій краӥн-учасниць можуть вести переговори про взаємне усунення перешкод на рівні міждержавних відносин. Визначивщись, щзо ті "виміри" економіки, в яких домінує "символічне посередництво" відносин - фінансовий ринок та споживання, зумовлені споживацтвом, - найбільш сприйнятливі до глобалізації. Набагато мени глобалізованими $\epsilon$ товарне виробництво та ринок праці. $€$ й теоретичні обгрунтування необхідності руху світової спільноти по иляху стандартизації в галузі економіки. Вони знайтли своїх прихильників в ідеї поєднання, взаємопроникнення, збагачення начіональних шляхів розвитку господарства не простим пристосуванням їх до загальних тенденцій через руйнування $i$ придушення, а способом з'єднання на принципах рівності, колективізму, збереження традиційної спрямованості розвитку. Певний розвиток теоретичних поглядів на прочеси впливу глобалізації на економічні прочеси конкретних країн ми знаходимо в роботах фахівиів Римського клубу, а також представників багатьох міжнародних урядових $i$ неурядових організацій. У них детально аналізуються самі процеси глобалізащії та перешкоди, щฺо постають на їхньому иляху. При изьму виділяються зовнішні межі - межі, щзо виникають $з$ минулого, і внутрішні межі - межі, щзо виникають з майбутнього, якими народжена більш небезпечна альтернатива глобалізачії -рух антиглобалізму. Отже, навряд чи доречно говорити про глобалізацію лише як про прочес безперервного зростання взаємної торгівлі, інвестицій, збільшення взаємозалежності краӥн та транскордонних територій. Таке розуміння глобалізації було б занадто спрощеним і поверхневим і не виявляло б якісно нових елементів процесу глобалізації з урахуванням проявів спещиифічного розвитку Карпатського єврорегіону.

Ключові слова: транскордонне співробітництво; карпатський євро регіон; міжнародні економічні зв'язки; глобалізаџія; світова економіка 
Key words: cross-border cooperation; Carpathian euro region; international economic relations; globalization; world economy.

Formulation of the problem. The modern stage of development of international economic relations is characterized by the rapid growth of world markets of all factors of production, the interaction of which forms the basis for combining local production processes into a unified system of reproduction of public product. Transnational cooperation, which organically combines market and planned methods of economic management, is one of the types of institutional formations that ensure effective interconnection between the micro- and macrolevels of the world economy. Periodically published statistics of international organizations show that transnational cooperation is one of the most dynamic modes of social reproduction, which has spread worldwide thanks to the free movement of goods, capital and technology to expand production and marketing capacity. Including domestic enterprises in this process is a priority for transition economies which need to attract cheap factors of production from abroad in order to increase the competitiveness of local big businesses.

Globalisation, like any other socio-economic process, is characterised by crises and upheavals. Practice shows that many of the complex problems generated by it can only be solved at the interstate or trans-country level. In particular, the peculiarities of the development of the Carpathian Euroregion have to be taken into account.

Analysis of recent research and publications. Much attention to these issues have been paid by the following researchers and scientists in cross-border cooperation: Duke R., Marc J. (France), Locatelli R., Chudi G.-M. (Switzerland), Gabbe G., Mudrich G., Klip K. (Germany); Eberhardt P., Stasiak A., Zolo Z. (Poland); Zardi A. (Italy); Borisov B., Ilieva M. (Bulgaria); Kuzmishin P., Tei Yu., (Slovakia), as well as domestic scientists: Amosha O., Belenky P., Broyde Z., Budkin V., Burakovsky I., Burkinsky B., Vnukova N., Vyshnyakov O., Hakman S., Guk A., Evdokimenko V., Kuybida V., Kozoriz M., Legenko Yu., Lendiel M., Lutsyshyn N., Lyashenko V., Makogon Yu., Malsky M., Melnyk A., Miklovda V., Mokiy A., Pila V., Pirozhkov S., Pisarenko S., Pukhtinsky M., Romanyuk S., Romanova N., Syromolot E., Studennikov I., Tkachuk A., Chmyr O., Chaika N., Shevchuk K., Shcherbak N. and others.

Formulation of the goals of the article. The aim of the article is to systematize theoretical approaches to defining the concept of cross-border cooperation and the peculiarities of its implementation in the Carpathian Euroregion in the development of international economic relations and globalization.

Presentation of the main research material. In the context of globalisation interstate borders in relation to economic relations have acquired a new meaning, which required the creation of a new system of regulation based on the principles of liberalisation, elimination of trade barriers, ensuring free movement of capital, etc. An urgent need was the development of a joint currency and financial policy, the achievement of stability in this area, capable of ensuring the convertibility of national currencies, facilitating mutual settlements [4, p.26]. The difference in the living standards of the inhabitants of different countries has raised the question of providing assistance and support from the developed countries to the developing states, and among them - to the least developed and poorest ones. A special role in the search for new regulatory mechanisms in the prevailing conditions was entrusted to international economic organizations, their participation in projects and programmes for the development of transcountry territories, and in particular the Carpathian Euroregion.

The creation of these interstate institutions was necessitated by the need to address formally different but interrelated tasks.

On the one hand, the process of economic globalisation highlights the problems and contradictions remaining at the national level between the regulatory functions of state administrative bodies and the needs of unimpeded development of the Carpathian Euroregion. In this respect, inter-state institutions, as well as the harmonised legal norms underpinning them, prevent attempts to disrupt the competitive environment at the regional level.

On the other hand, multilateral organisations are the mechanisms within which representatives of national administrations of the participating countries can negotiate the mutual removal of obstacles at the level of inter-state relations. In other words, the activity of international organizations allows "clearing the way" for globalization processes both on national and regional levels [1, p.51].

There are theoretical justifications of the necessity of movement of the world community on the way of standardization in the field of economy. They found their adherents in the idea of combination, interpenetration, enrichment of national ways of development of economy not simply adjusting them to the general tendencies through destruction and suppression, but the way of connection on principles of equality, collectivism, preservation of traditional orientation of development.

Neoclassical liberalism ignores the problem of understanding specific socio-economic differences in the conditions and constraints of different types of national economies. Therefore, its methodological approaches often promote simple retranslation of the laws of functioning of one particular historical economic system to another [4, p.26]. The analysis of globalisation processes in the framework of these approaches cannot reflect any real content and regularities of their development.

A certain development of theoretical views on the processes of globalisation influence on economic processes of specific countries we find in the works of specialists of the Club of Rome, as well as representatives of many 
international governmental and non-governmental organisations. They analyse in detail the processes of globalisation themselves and the obstacles that stand in their way. At the same time, external limits - limits arising from the past, and internal limits - limits arising from the future, which give birth to a more dangerous alternative to globalization - the movement of anti-globalization. Scholars of this direction investigate the structural features of globalisation: the subordination of national economies to the interests of MNCs and international trade and financial institutions; resistance to this subordination; the opposition of globalism and Islamic fundamentalism.

In the course of globalization, a "global cultural flow" is formed, which breaks up into five cultural and symbolic spaces-flows (landscapes): ethnoscape is formed by the flow of tourists, immigrants, refugees, guest workers; technoscape by the flow of technology; finanscape by the flow of capital; mediascape by the flow of images; ideoscape by the flow of ideology. These fluid, unstable spaces are the "building blocks" of those "imaginary worlds" in which people interact, and this interaction is characterized by symbolic exchanges. The globalisation of society is therefore a process defined by the predominance of culture over economics and politics [2, p.13]. Economy and politics are globalized to the extent that they are 'permeated' by symbolic exchanges.

Those "dimensions" of the economy dominated by the "symbolic mediation" of relations - the financial market and consumption driven by consumerism - are most susceptible to globalisation. Much less globalised are commodity production and the labour market.

Indeed, globalisation (especially in the economic sphere) should not be seen as a completely new and unique process. Rather, we can speak of several historical waves of development of the international economy, one of which is the modern period. Globalisation can be imagined not as a constantly increasing linear process, but rather as a process with peaks and troughs, i.e. periods of development and contraction, and sometimes even stagnation.

Thus, it is hardly appropriate to speak of globalisation only as a process of continued growth of mutual trade, investment, increasing interdependence of countries and transcountry territories. Such an understanding of globalisation would be too simplistic and superficial and would not reveal qualitatively new elements of the globalisation process taking into account the manifestations of the specific development of the Carpathian Euroregion.

Although the notion of globalisation, taking into account all the manifold manifestations of this process, is established in theory as a concept expressing the complex interrelations and changes of the modern world, many problems and questions still remain open. New challenges to theoretical constructions require explaining the myriad empirical contradictions and exploring alternatives to development within this process.

The consequences of globalisation are ambiguous: Globalisation deepens specialisation and the international division of labour. Under it, funds and resources are allocated more efficiently, which ultimately contributes to higher average living standards and better life prospects for the population (at a lower cost to them) [6, p.20].

An important benefit of globalisation processes is economies of scale, which have the potential to reduce costs and prices and thus lead to sustained economic growth.

Globalisation, by increasing competition, stimulates the further development of new technologies and their diffusion among countries. Under its conditions, the growth rate of direct investment far exceeds the growth rate of world trade, which is a crucial factor in the transfer of industrial technology, the formation of transnational companies, which has a direct impact on national economies. The advantages of globalisation are determined by the economic benefits that are derived from the use of advanced scientific, technological and qualification level of leading foreign countries in relevant fields in other countries, in these cases the introduction of new solutions takes place in a short time and at relatively lower cost.

Globalisation contributes to increased international competition within the Carpathian Euroregion. It is sometimes argued that globalisation leads to perfect competition. In reality it is rather a question of new competitive fields and more fierce competition on traditional markets, which is beyond the reach of any one state or corporation [3, p. 23]. For the domestic competitors are joined by powerful external competitors with unlimited scope for action. The globalisation of the world economy benefits consumers first and foremost, as competition gives them choice and lowers prices.

Globalisation can lead to increased productivity as a result of the globalisation of production and the diffusion of advanced technology, and competitive pressure for continuous innovation on a global scale.

Globalisation offers the trans-Carpathian Euroregion an opportunity to mobilise a greater volume of financial resources, as investors are able to use a wider range of financial instruments in an increased number of markets [5, p.151].

In the process of globalisation, a new framework for the world economic system is emerging, characterised by the following shifts.

1. The distinction between the internal and external environment of activity, between domestic and foreign policy is being erased; the economisation of policy is rapidly gaining momentum, with geo-economic space becoming paramount.

2. The mobile trans-border reproductive systems, formed globally in the most promising areas of technological development and resource endowment, have brought the military component to new frontiers. The armed forces are functionally transformed, they protect not only the sovereignty of states and their national borders, but also mainly the economic borders (geoeconomic interests, bridgeheads, prerogatives) of transnationalized structures, maintaining the contours of internationalized reproductive cores (cycles) [8, p.6]. This fundamentally changes the approach to military reform, military composition and armaments. 
3. Under these conditions, the role of nation states is being transformed, the most developed of them turning into transnationalised "system countries". They can no longer ignore supranational trends in the economic, informational, financial, social, military and other spheres [7, p.21]. They begin to play the role of a global entrepreneur, delegate the function of implementing strategic national interests and aspirations to powerful financial and banking structures, transnational corporations, consortia, unions, etc.

4. The foreign policy motivation changes fundamentally: the "country-system" generates global income within its internationalized reproduction cores. Participation in its formation and distribution is the highest motivational incentive for national economies to operate economically in the world economic system: diplomacy takes it in its stride [10]. The breakthrough to participation in global income is made through the use of high geo-economic technology.

5. Traditional foreign economic (foreign trade) doctrines are losing their power. Foreign trade no longer mediates only the division of labour between nations, states (international division of labour). It is no longer operating in the world market, but in a new strategic space - the geo-economic atlas of the world, including its national parts [9]..

6. International organizations and institutions, born in the post-war period for the sake of certain geopolitical goals, in the context of the geo-economic transformation of the world have exhausted their resources: the formation of a new system of world economic structures, reflecting the geo-economic realities, including the need for an international institution such as a geo-economic tribunal, is on the agenda.

7. The emergence of powerful supranational structures in the geo-economic space has not only significantly weakened national sovereignties, but has also become a self-sufficient, self-organising and self-developing system. This is particularly characteristic of the credit and financial sphere. Having lost touch with reproductive cycles, the movement of global financial flows has led to a proliferation of hard-to-manage speculative capital and distorted national financial and credit relations [11, p.39].

Conclusions. Considering the above, it becomes evident that Considering the above, it becomes evident that there is no unified concept of globalisation at the level of the transcountry territory of the Carpathian Euroregion. On the contrary, there are many theoretically contradictory approaches and points of view, which confirms the lack of a clear methodology and conceptual clarity of concepts. The flaws of globalisation stem from technological determinism (information technology cannot "make" the new society), simplistic approaches to the problem (reducing a set of socially significant processes to one aspect), instrumentalism (identifying the concept of globalisation with the realities of global trends) and discrediting the concept of convergence.

\section{References.}

1. Bilous, O. (2007), "Problems of Political Economy of Globalism. Globalism as a world system of imperialist integration", Ukraina $\mathrm{v}$ hlobalizovanomu sviti [Ukraine in a globalized world], Zbirnyk nauk. prats' [Collection of scientific works], NAN Ukrainy. In-t svitovoi ekonomiky i mizhnarodnykh vidnosyn, 176 p.

2. Bilous, O. (2008), "The current global financial and economic crisis as a manifestation of the total crisis of the system of globalism”, Ekonomichny`j chasopy`s, Vol. 11-12, pp. 12-15.

3. Galchinsky, A. (2005), "Global Transformations: Lessons for Ukraine”, Polity 'ka i chas, Vol. 8, pp. 18- 28.

4. Dzhyndzhoian, V. and Konon, N. (2009), "Informatization in the production management system in the conditions of globalization of the world economic space", Ekonomika: problemy teorii ta praktyky, Vol. 248, Is. I, pp. $22-28$.

5. Kuzmenko, A. (2005), "Features of modern competition of "groups of influence and pressure" with the public power of the states: control over special services (intelligence and counterintelligence) - a sign of real power", Dialoh tsyvilizatsij: mistse i rol' latentnykh struktur v upravlinni svitom [Dialogue of civilizations: the place and role of latent structures in governing the world], Zbirnyk nauk. prats'. Tret'oyi vsesvitn oyi konferenciyi, 28 trav. 2004 r. [Proceedings of the Third World Conference, May 28. 2004], MAUP, pp. 146-160.

6. Novitsky, V. (2009), “The Global Financial and Economic Crisis: Essence, Systematic Manifestation and Prospects for Overcoming”, Ekonomichny`j chasopy`s - XXI, Vol. 1-2, pp. 18-21.

7. Reznikova, N. (2006), "Trends and Prospects for the Development of the World Economy: Regional Aspect", Personal, Vol. 6, pp. 20-24.

8. Rukomeda, R. (2002), "To the concept of transformation: essence and characteristic manifestations in world practice", Stratehichna panorama, Vol. 4, pp. 5-7.

9. Sazonets, I. Gladchenko, A. and Hessen, A. (2016), Sotsial'no-ekonomichni determinanty hlobal'noi rivnovahy [Socio-economic determinants of global equilibrium], Volin. Amulets, Rivne, Ukraine.

10. Toryanik, V. and Dzhyndzhoian, V. (2018), Bezpeka turyzmu [Tourism Security], Dnipro University of the Humanities, Dnipro, Ukraine.

11. Sardak, S. Korneyev, M. Dzhyndzhoian, V. Fedotona, T. and Tryfonova, O. (2018), "Current trends in global demographic processes", Problems and Perspectives in Management, LLC "Consulting Publishing Company "Business Perspectives", Vol. 16, Is. 1, pp. 48-57.

Стаття надійшла до редакиї 20.11.2020 p. 